\title{
ORT_16 - Improvement of Vero cell culture conditions and new approaches for Zika virus production targeting immunobiologicals development
}

Rafael Araújo Mendonça ${ }^{1 *}$; João Carlos Rodrigues da Silva ${ }^{1}$; Tiago Pereira dos Santos ${ }^{1}$; Lecila Coelho Macedo Andrade ${ }^{1}$; Guilherme de Jesus da Silva ${ }^{1}$; Kelly Araújo Lúcio ${ }^{1}$; Sheila Maria Barbosa de Lima ${ }^{1}$; Ygara da Silva Mendes ${ }^{1}$; Marta Cristina de Oliveira Souza ${ }^{1}$.

${ }^{1}$ Fiocruz/Bio-Manguinhos.

Introduction: Since Zika virus (ZIKV) outbreaks led to the discovery of the association of this viral infection with Guillain-Barr? and congenital Zika syndromes, many efforts have been made to develop better immunobiologicals and more suitable experimental tools to treat, prevent, diagnose and study this infection. To make this possible, in many cases, an optimized production process can be the key for a consistent in vitro viral propagation in large-scale. In this context, one of the main continuous cell lines used for ZIKV replication is the Vero ATCC ${ }^{\circledR}$ CCL- $81^{\mathrm{TM}}$ cell line, which the World Health Organization certifies as safe for the production of viruses for vaccine purposes.

Objective: The aim of this study is to optimize cell growth and to select the best operation mode for ZIKV production process, comparing the discontinuous and semi-continuous modes after the Time of Infection (TOI).

Methodology: We carried out a design of experiments to optimize growth of Vero ATCC ${ }^{\circledR}$ CCL- $81^{\mathrm{TM}}$ cells in spinner flasks using semi-continuous operating mode. Vero cells were cultivated in VP-SFMTM medium at nine different conditions using as variables different input concentrations of cell inoculum, Cytodex $^{\circledR} 1$ microcarriers and poloxamer 188 surfactant. We selected the best condition of cell growth and compared three different conditions for ZIKV production. Two of them operating in semi-continuous mode after each TOI (3rd and 5th cultivation day), exchanging $75 \%$ of medium volume every $24 \mathrm{~h}$, and the third condition operating in discontinuous mode until the glucose concentration reach values close to $0.5 \mathrm{~g} / \mathrm{L}$. The Multiplicity of Infection (MOI) used was of 0.02 . We compared both conditions in terms of viral production and yield, using plaque assay to determine viral titers.

Results: One of nine conditions of the design of experiments (input concentrations of $6 \times 105$ cells $/ \mathrm{mL}, 2 \%$ $\mathrm{w} / \mathrm{v}$ of poloxamer 188 and $2 \mathrm{~g} / \mathrm{L}$ of Cytodex $\left.{ }^{\circledR} 1\right)$ reached almost $3 \times 10^{6}$ cells $/ \mathrm{mL}$, a cell density greater than found in the other conditions $\left(0,5-1,0 \times 10^{6} \mathrm{cell} / \mathrm{s} / \mathrm{mL}\right)$. Using the optimized cell growth condition, the semicontinuous operating mode conditions showed a ZIKV production of 9.06 and $1.74 \times 10^{7} \mathrm{pfu}$ and yielded 8.24 and $2.18 \times 10^{4}$ pfu per $\mathrm{mL}$ of VP-SFMTM consumed for, respectively, the $3^{\text {rd }}$ and $5^{\text {th }}$ day TOI. These results are greater than the results reached by discontinuous operating mode $\left(6.55 \times 10^{6} \mathrm{pfu}\right.$ and yield of $\left.1.87 \times 10^{4} \mathrm{pfu} / \mathrm{mL}\right)$.

Conclusion: These results show that we found the optimized condition for Vero cell growth in semicontinuous mode. Moreover, we showed that the best operation mode for a consistent ZIKV production is the semi-continuous one with medium exchange every $24 \mathrm{~h}$. This work has highlighted the importance of medium exchange during viral production for an efficient process, desired for vaccine and other immunobiologicals development and production.

Keywords: Zika virus; Vero cell; Microcarries 